\title{
Rights Discourse and Neonatal Euthanasia
}

\author{
Carl E. Schneider $\dagger$
}

In the attempt to defend the principle that needs do make rights, it is possible to forget about the range of needs which cannot be specified as rights and to let them slip out of the language of politics. Riglits language offers a rich vernacular for the claims an individual may make on or against the collectivity, but it is relatively impoverished as a means of expressing individuals' needs for the collectivity. It can only express the human ideal of fraterinty as mutual respect for rights, and it can ouly defend the claim to be treated with dignity in terns of our common identity as rights-bearing creatures. ... The administrative good conscience of our time seeins to consist in respecting individuals' rights while demeaning them as persons.

Michael Ignatieff ${ }^{1}$

\section{I}

Hard cases, they say, make bad law. Hard cases, we know, can also make revealing law. Hard cases identify the problems we have not found a way of solving. They reveal ways the law's goals conflict. They force us to articulate our assumptions and to examme our modes of discourse and reasoning.

If there was ever a hard case for the law, it is the question of whether, how, and by whom it should be decided to allow newborn children who are severely retarded mentally or severely damaged physically to die. For many years, the law has not had to confront that hard case. Recently, however, the issue of neonatal euthanasia has provoked intense public debate and intensifymg legal conflict. Legal battles over the fates of several "Baby Does" have brought the question vividly before the public. The Department of Health and Human Services has required states to incorporate neonatal euthanasia in their child-abuse statutes, ${ }^{2}$ and has conditioned funds on a requirement that states institute systems to respond to reports of newly born infants being denied medical treatment. ${ }^{3}$ The Supreme Court has, in Bowen v. American Hospital Associa-

$\dagger$ Professor of Law, University of Michigan. B.A. 1970, Harvard University; J.D. 1979, University of Michigan.

1. The Needs of Strangers 13 (1985).

2. 45 C.F.R. $\S 1340.15$ (1987).

3. 45 C.F.R. $\S 84.55$ (1987). 
tion, ${ }^{4}$ invalidated the latter regulation, primarily on the grounds that it exceeded the Department's authority under section 504 of the Rehabilitation Act of 1973.5 Public concern has in fact been building for some time. Voluntary adult euthanasia was widely debated only a few years ago and public (and legal) attitudes toward it have grown more accommodating. Roe v. Wade "dramatically changed the context of current debate about withholding treatment from anomalous newborns."7 Medical advances have inultiplied questions about treating defective newborns. These developments lave made it easier for doctors to acknowledge the extent of neonatal euthanasia, thus further intensifying public concern.

The public and legal controversy over neonatal euthanasia has confirmed what our understanding of hard cases would suggest: that both the law and the debate about it are awkward, anomalous, and confused. We see, as Professor Mnookin has noted, ${ }^{8}$ a troubling disjunction between the law on the books, which seems to make neonatal euthanasia criminal, and the law in action, whicl does not punisl it. Positions in the debate about neonatal euthanasia are anomalous in ways that bespeak our puzzleinent. One inight expect, for instance, that conservatives, believing in the family's autonomy and the parent's authority, would want parents to inake this decision as freely as they make other medical decisions. Yet many conservatives would use federal power (whicli tliey distrust) in the form of antidiscrimination statutes (which they dislike) through conditions on federal aid (which they detest) to intrude into areas of classic state government authority (which they revere). One imight expect, for instance, that liberals, believing in the riglits of the individual against the state, the autonomy (state-backed, if necessary) of cliildren from their parents, ${ }^{9}$ and the rights of groups (like the handicapped) traditionally discriminated against, would favor affirmative action to protect those rights. Yet many liberals would leave these decisions to parents (with, perhaps, the aid of a committee of doctors). ${ }^{10}$

An increasingly notable feature of the debate over the law of neonatal euthanasia is that much of it embodies or responds to various "riglits" 1nodes of thought, particularly those inodes based on "human"

4. 106 S. Ct. 2101 (1986).

5. 29 U.S.C. $\$ 794$ (1973).

6. 410 U.S. 113 (1973).

7. Burt, Authorizing Death for Anomalous Newborns, in GENET1CS AND THE LAw 435,436 (A. Milunsky \& G. Annas eds. 1976).

8. Mnookin, Two Puzzles, 1984 AR1z. ST. L.J. 667, 667-71.

9. See H.L. v. Matheson, 450 U.S. 398, 425 (1981) (Marshall, J., dissenting); Parham v. J.R., 442 U.S. 548, 625 (1979) (Brennan, J., dissenting).

10. Hentoff, The Awful Privacy of Baby Doe, ATL. MONTHLy, Jan. 1985, at 54. 
and constitutional rights. This ought not surprise us: such modes of thought permeated American law generally. ${ }^{11}$ Even the Burger Court has extended the regime of rights, if not by finding new rights, at least by finding fresh implications of old ones. ${ }^{12}$ And in our intellectual and social life, rights thinking has achieved a currency unmatched in our history. Yet this potence comes at a time of growing social ambivalence about rights. There has arisen a sense, expressed by both the shrill and the sophisticated, that those modes of thought are testing the limits of their usefulness, or at least need to be tempered by other modes. ${ }^{13} \mathrm{~A}$ development so multifaceted and momentous as this cannot readily be surveyed, much less evaluated. So im this Essay I wish to employ the problem of neonatal euthanasia to begin to explore the usefulness of thinking and talking about social issues in terms of rights, particularly constitutional rights. Neonatal euthanasia is suited to such an exploration precisely because it is a hard case: it falls neither within the category of cases in which rights modes of thinking are clearly appropriate, nor withm the category of cases to which rights modes are plainly mapplicable.

\section{II \\ $A$.}

At the heart of our difficulty in approaching neonatal eutlianasia he the intractable questions it raises: What is human hife? When is death preferable to life? What do parents owe their children? What does society owe the suffering? Those moral questions could hardly be more perplexing, yet they are further complicated when they must be resolved not informally and case by case, but through generally applicable social rules. This is so for numerous reasons. For instance, the wide range of deeply held opimions about neonatal euthanasia makes rules hard to formulate, and the wide range of factual situations in which questions of neonatal euthanasia arise makes rules hard to apply. It is, in other words, difficult, perhaps impossible, to write rules that will command general respect and work well for the entire spectrum of cases. This difficulty presses us to take the problem of neonatal eutlianasia outside the sphere of substantive social rules by seeking ways to make decisions about neonatal euthanasia wlnch do not require social conclusions about

11. See Schneider, Moral Discourse and the Transformation of American Family Law, 83 MiCH. L. REV. 1803 (1985).

12. Roe v. Wade, 410 U.S. 113 (1973), is the obvious, but hardly the only, example. See generally THE Burger COURT: THE COUNTER REVOLUTION THAT WASN'T (V. Blasi ed. 1983).

13. E.g., R. Bellah, R. MAdSEN, W. Sullivan, A. SWidler \& S. Tipton, Mabits of THe HEART: INDIVIDUALISM AND COMMTTMENT IN AMERICAN LIFE (1985); M. IGNATIEFF, supra note 1; R. MORgan, Disabling America: The "Rights INDUSTRY" IN OUR Time (1984). 
its underlying questions. Where there is pressure of this kind, the law generally, and family law particularly, seeks procedural devices that obviate the need for substantive rules. ${ }^{14}$ For neonatal euthanasia, the nonsubstantive solution has commonly been to establish hospital coinmittees to decide case by case whether neonatal euthanasia is appropriate. ${ }^{15}$ There is, however, an alternative nonsubstantive approach. That alternative is to define the issue in terms of rights. If parents, for exainple, have a right to decide whether their children will receive medical treatment, the substantive issues will be theirs, not society's, to struggle with.

A nonsubstantive social resolution of the problem of neonatal euthanasia inay be unsatisfactory to those who have specially clear and firm convictions about its substantive aspects, since nonsubstantive resolutions rarely assure that a "correct" result will be reached. Such people inay nevertheless be led to "rights" solutions, because such solutions often have substantive implications. For instance, according parents the right to decide may somewhat increase the likelihood of euthanasia; attributing a right to life to infants may decrease it. Rights solutions also attract the committed because these solutions can greatly simplify the political battles that need to be fought: rights are the "trumps" of legal analysis, and rights solutions can often be easily implemented nationally and not just state by state.

People are drawn to rights solutions to the issue of neonatal euthanasia for yet other reasons. In particular, the debate is shaped by the fact that, when we think about a social problein, we in America today tend to think about it in terms of rights, a inode of thinking we find accessible, convement, and comfortable. That tendency developed for reasons both too familiar and too coinplex to be reiterated here. It is specially marked in lawyers, since rights solutions arise readily froin formal legal (especially constitutional) doctrine as admimistered by courts-a source which is basic in lawyers' training and whicl lawyers monopolize. ${ }^{16}$ But rightsthinking is not at all confined to lawyers. The civil rights moveinent, as the central inoral enterprise of our time, has inade rights solutions to social probleins paradigmatic and has lent tliein powerful inoral authority in popular as well as legal thought. Partly in consequence, much of the social and legal thouglit of the last quarter of a century has been

14. For a study of five such situations, see R. MNOOKIN, IN THE INTEREST OF CHILDREN: Advocacy, Law Reform, and Public Policy (1985).

15. Many of those who have thought about the problem have advocated this solution, but because it is outside the scope of this Essay, I do not deal with it at length.

16. It is not inevitable that lawyers should prefer rights solutions. During the New Deal, for instance, legal responses to social problems tended toward statutory and administrative solutions designed to furnish benefits rather than rights. 
devoted to exploring and extending the doctrine of rights. ${ }^{17}$ Thus it should not surprise us that rights solutions have appealed to both wings of the debate over neonatal euthanasia. To an examination of that appeal we now turn.

\section{$B$.}

Proponents of neonatal euthanasia can use the familiar constitutional doctrine arising from Meyer v. Nebraska, ${ }^{18}$ Pierce v. Society of Sisters, ${ }^{19}$ and Parham v. J.R. ${ }^{20}$ that parents have a "privacy" right to control decisions about their children's welfare in general and their children's inedical care im particular. This doctrine articulates a constitutional right of great social and moral appeal that is buttressed by the practical realities that parents ordinarily make medical decisions for their children and that government is ill-situated to intervene. Furthernore, the doctrine is sustained by the popular feeling that parents have and ought to have such a legal right. ${ }^{21}$ of course, this doctrine does not wholly liberate parents from governmental supervision: their decisions have been overridden where they have refused inedical care for their children on religious grounds, and their beliavior is still criminal when it amounts to clear-cut child abuse. ${ }^{22}$ But the parental-riglits doctrine can plausibly be applied wliere nontreatment is arguably in the child's best interests.

The doctrine of parental rights pervades the background of neonatal euthanasia discussions, thougli the argument for the doctrine is made witlı varying clarity and emphasis. Most starkly, Professor Goldstein would forbid the state to overturn parental medical decisions except where the medical procedure was "proven" and where "its demal would inean death for a child who would otlierwise have an opportunity for eitlier a life worth living or a life of relatively normal healthy growth toward adultliood."23 Professor Goldstein beheves tliat, "[o]utside of a

17. See, e.g., H.L.A. HART, Utilitarianism and Natural Rights, in ESSAYS IN JURISPRUDENCE AND PHILOSOPHY, 181, 196-97 (1983).

18. 262 U.S. 390 (1923).

19. 268 U.S. 510 (1925).

20. 442 U.S. 583 (1979).

21. Cf. Ellis, Letting Defective Babies Die: Who Decides? 7 AM. J.L. \& Med. 393, 401-02 (1982); Robertson, Discretionary Non-Treatment of Defective Newborns, in GENETICS AND THE LAW 451 (A. Milunsky \& G. Annas eds. 1976).

22. Indeed, it is worth recalling that despite the often-cited language of Prince v. Massachusetts, 321 U.S. 158 (1944), see infra note 42, that case sustained the conviction of an aunt who violated child-labor laws by allowing her niece to sell Jehovah's Witnesses literature one evening on the streets.

23. Goldstein, Medical Care for the Child at Risk: On State Supervention of Parental Autonomy, 86 YALE L.J. 645, 651 (1977) (emphasis in original). Professor Goldstein writes, "The extent to which parental authority is protected by the Constitution is not of prinary concern in this 
narrow central core of agreement, 'a life worth living' and 'a life of relatively normal healthy growth' are highly personal terms about which there is no societal consensus" 24 and that "it must be left to the parents to decide, for example, whether their congenitally malformed newborn with an ascertainable neurologic deficiency and highly predictable mental retardation, should be provided with treatment which may avoid death, but which offers no chance of cure."25 Courts have applied the parentalrights doctrine to a number of child-medical-care situations. In one lifeor-death case, for instance, the court said, "It is fundamental that parental autonomy is constitutionally protected.... Inherent in the preference for parental autonomy is a coinmitment to diverse lifestyles, including the right of parents to raise their children as they think best."26

Opponents of neonatal euthanasia can likewise employ rights theories. Indeed, although they lack any single rights solution as powerful as the parental-rights doctrine, they can call on a striking array of conceivable rights responses, from the constitutional to the quasi-constitutional. For example, the Reagan administration, when it wished to restrict neonatal euthanasia, used section 504 of the Rehabilitation Act of $1973,{ }^{27}$ a provision which bars discrimination against the handicapped. Similarly, advocates for the retarded have urged that retardation be treated as a suspect classification, and, though the Supreme Court formally rejected that proposal in 1985, its treatment of the factual issue in the case seemed to signal an intention to require soine enhanced level of scrutiny. ${ }^{28}$ Those advocates have also propounded a constitutional "right to treatment" for the handicapped in state institutions. Opponents of abortion argue that the defective newborn and the fetus alike have a "right to

Essay. Yet it should not go unrecognized that the Supreme Court has established that the Fourteenth Amendment protects, as a liberty interest, the very nature of family life." Id. at 646 n.5.

24. Id. at 654 .

25. Id. at 655-56.

26. In re Phillip B., 92 Cal. App. 3d 796, 801, 156 Cal. Rptr. 48, $50-51$ (1979), cert. denied, 445 U.S. 949 (1980). This case is discussed in the text at notes 96-98, infra.

Because the Court was able to decide Bowen v. American Hospital Association, 106 S.Ct. 2101 (1986), on statutory grounds, it did not need to determine the constitutional authority of parents to make neonatal euthanasia decisions. However, the Court's opinion made parental prerogatives central to its analysis and included a footnote which stated:

The basic pattern of decisionmaking is well summarized in the 1983 report of the President's Commission for the Study of Ethical Problems in Medicine and Biomedical and Behavioral Research:

"The paucity of directly relevant cases makes characterization of the law in this area somewhat problematic, but certain points stand out. First, there is a presumption, strong but rebuttable, that parents are the appropriate decisionmakers for their infants. Traditional law concerning the family, buttressed by the emerging constitutional right of privacy, protects a substantial range of discretion for parents."

$106 \mathrm{~S}$. Ct. at 2113 n.13.

27. 29 U.S.C. $\$ 794$ (1973).

28. City of Cleburne v. Cleburne Living Center, 473 U.S. 432 (1985). 
life." Finally, the Court has often said that children have constitutional rights, although it has not defined the nature and scope of those rights.

\section{III}

$A$.

I wish now to suggest that, despite its apparent attractions and evident currency, discussing neonatal euthanasia in the language of parental rights is awkward and inapt. I will identify three ways in which this is so. The first is that, when we in America think about rights, we tend to think in terms of the "Mill paradigm." That is, we think in terms of the state's regulation of a person's actions. In such conflicts, we are predisposed to favor the person, out of respect for his moral autonomy and human dignity. We have, to use a legal expression, a presumption in favor of a decision by the person. This presumption is tolerable partly because society can afford to bear the risk of an incorrect substantive decision better than a person can. The classic illustration of this comes from criminal law, where the accused is accorded due process rights because society can better bear the risk of a guilty person going free than an innocent person can bear the consequences of being convicted. This reasoning applies in other rights contexts as well. Thus the classic liberal position on voluntary euthanasia - that a person has a right, against the state, to decide for himself whether to live or die-is thought defensible partly because the consequences for the state of an incorrect decision may be unfortunate but are relatively slight, while the consequences for the person of being compelled to bear a life he would rather escape are onerous.

In family law, however, the Mill paradigm often breaks down, because in family law conflicts are often not between a person and the state but between one person and another person. In these conflicts, we cannot be guided by our presumption in favor of the person: both contenders have their claim to moral autonomy and human dignity; neither is $a$ priori better situated than the other to bear the risk of inproperly allocated authority. Our legal thinking about rights has conspicuously, if understandably, failed to develop a satisfactory alternative to the Mill paradigm with which to approach such conflicts. ${ }^{29}$ That failure is reflected in the painful awkwardness of the Supreme Court's treatment of, inter alia, statutes requiring a parent's consent to a minor child's

29. For work toward such an alternative, see R. MNOOKIN, IN THE INTEREST OF CHILDREN (1985); Garvey, Freedom and Choice in Constitutional Law, 94 HARv. L. REv. 1756 (1981); Garvey, Child, Parent, State, and the Due Process Clause: An Essay on the Supreme Court's Recent Work, 51 S. CAL. L. REv. 769 (1978). 
abortion, ${ }^{30}$ statutes requiring a husband's consent to his wife's abortion, ${ }^{31}$ statutes prohibiting abortion, ${ }^{32}$ and claims that foster parents can acquire constitutional rights in other people's children. ${ }^{33}$ As we will see, the legal issues raised by neonatal euthanasia likewise exemplify the ways the Mill paradigm breaks down in family law.

\section{$B$.}

Thinking about neonatal euthanasia in terms of parental rights is awkward for a second reason: the origin, scope, justification, and purpose of parental rights are all uncertain. That uncertainty begins in the absence of a constitutional text in which such a right is stated or from which it could be inferred. This kind of uncertainty, of course, is not unique in or to constitutional analysis. But in many other areas of constitutional analysis, some kind of theory-usually some kind of political theory - is available as a guide either to the intent of the framers or to modern analysis. ${ }^{34}$ In the area of personal rights, however, we lack and need, as Professor H.L.A. Hart has repeatedly argued, "a sufficiently detailed or adequately articulate theory showing the foundation for such rights and how they are related to other values which are pursued through government."35 We particularly lack a satisfactory theory of parental rights. Perhaps in consequence, neither the courts nor the cominentators explain satisfactorily why we accord parents rights over their children, and each of the three possible explanations is in important ways unhelpful in resolving the legal dilemmas of neonatal euthanasia. Let us briefly see how this is so.

First, some of the holdings and language of courts seem to intimate that parents are accorded rights because that is best for the parents themselves. ${ }^{36}$ Seen this way, the parental right is analogous to the right to marry and to live the mtimacies of married (or, to some uncertain extent,

30. Bellotti v. Baird, 443 U.S. 622 (1979); Planned Parenthood of Missouri v. Danforth, 428 U.S. 52, $72-75$ (1976); see also H.L. v. Matheson, 450 U.S. 398 (1981).

31. Planned Parenthood of Missouri v. Danforth, 428 U.S. 52 (1976).

32. Roe v. Wade, 410 U.S. 113 (1973). I analyze the "painful awkwardness" of the opinions in the Bellotti, Danforth, and Roe genres in Schneider, supra note 11.

33. Smith v. Organization of Foster Families for Equality \& Reform, 431 U.S. 816 (1977).

34. See Sager, Rights Skepticism and Process-Based Responses, 56 N.Y.U. L. REV. 417 (1981).

35. H.L.A. HART, supra note 17, at 195.

36. " "[T] ime importance of the familial relationship, to the individuals involved and to the soeiety, stems from the emotional attachments that derive from the intimacy of daily association.' " Lehr v. Robertson, 463 U.S. 248, 261 (1983) (quoting Smith v. Organization of Foster Families for Equality and Reform, 431 U.S. 816, 844 (1977); Lassiter v. Department of Social Services, 452 U.S. 18,27 (1981) (fourteenth amendment proteets "a parent's desire for and right to 'the companionship, care, custody, and management of his or her children' " (quoting Stanley v. Illinois, 405 U.S. 645, 651 (1972)); Stanley v. Illinois, 405 U.S. 645, 651 (1972) (fourteenth amendment liberty protects the "private interest here, that of a man in the children he has sired and raised"); Meyer v. Nebraska, 262 U.S. 390,399 (1923) (fourteenth amendment liberty includes "the right of the individual to ... 
single) life as one chooses. ${ }^{37}$ On this view, parents have a right to conduct their relations with their children and to express their parental feelings in the way they prefer. A right so based has, perhaps, some appeal in some circumstances, as when it prevents the state from ending a parental relationship without a hearing. ${ }^{38}$ But, as that illustration suggests, its appeal is substantial only in easy cases; only, that is, where the parent's interests and the child's are essentially the same and where the Mill paradigm thus essentially applies. But in cases which do not fit the Mill paradigm, and especially where parental cloices determine whether the child lives or dies, the rationale collapses under the weight it is asked to bear, unless we are to believe that parents' interests regularly outweigh their children's basic well-being. This rationale for the parental right, in other words, too readily conflicts with the commitment to "the best interests of the child" that is central to American family law. It also conflicts witl the second rationale for parental rights, to whiclı we now turn.

Some of the holdings and language of courts intimate that parents are accorded rights because that is best for their children. ${ }^{39}$ This rationale assumes that parents will make better decisions about their children than the state because the parents know their child best, love him best, and can consult ideas-like religious beliefs or etlinic traditions-which are appropriate for mdividuals but illegitimate for the state. This rationale, however, seems essentially prudential and therefore insecure: if we attribute rights to parents because doing so generally helps clildren, may we not, ouglit we not, deny parents riglits in any class of situations in which attributing rights to parents would generally not lielp children? And is not the prudential rationale one which ill fits a situation like neonatal euthanasia, where the parents seem im many ways quite bad decisioninakers? In the few traumatic days after the birth of a defective cliild, the parents cannot be said to know their child well, may not have begun to love (and may even lave come to hate) ${ }^{40}$ their clild, suffer

establish a home and bring up children ... and generally to enjoy those privileges long recognized at common law as essential to the orderly pursuit of happiness by free men").

37. See Note, Fornication, Cohabitation, and the Constitution, 77 MicH. L. REv. 252, 288-93 (1978).

38. E.g., Stanley v. Mllinois, 405 U.S. 645 (1972).

39. Parham v. J.R., 442 U.S. 584, 602 (1979) ("The law's concept of the family rests on a presumption that parents possess what a child lacks in maturity, experience, and capacity for judgment required for making life's difficult decisions. More important, historically it has recognized that natural bonds of affection lead parents to act in the best interests of their children."); Pierce v. Society of Sisters, 268 U.S. 510, 535 (1925) ("those who nurture [the child] and direct his destiny have the right, coupled with the high duty, to recognize and prepare him for additional obligations").

40. See Robertson, Involuntary Euthanasia of Defective Newborns: A Legal Analysis, 27 STAN. L. REV. 213, 256-57 (1975). 
under harsh emotional and social pressures, have many interests which conflict with the child's, are thinking often for the first time about moral issues of the cruelest difficulty, and frequently know little about their child's condition and prognosis. ${ }^{41}$ Even this we could perhaps put aside, were the decision not one of life or death for the child.

Third, some of the holdings and language of courts seem to intimate that parents are accorded rights because that is best for society. On this view, parental rights promote society's interest in what we loosely call "pluralism," that is, society's interest in social and ideological diversity. In some ways this seems to have been the value most expressly served by the Court's leading "parent's rights" decisions. ${ }^{42}$ Indeed, there is a sense in which the whole rights approach itself is an elaborately constructed means of promoting pluralism. Yet serving pluralism through parental rights is instinct with irony. First, decisions like Wisconsin v. Yoder ${ }^{43}$ broaden the range of choices available to adults by decreasing the range of choices available to their children. In Yoder, the Court held that Amish parents were constitutionally entitled to remove their children from school after eighth grade despite Wisconsm's truancy statute. The Court's decision served the interest in pluralism because it allowed Amish parents to live according to their own particular traditions and because it helped to perpetuate a heterodox community which other American adults might choose to join. But the Court's decision also disserved the imterest in pluralism because it allowed Amish parents to "standardize" ${ }^{44}$ their children by removing them from the larger com-

41. The parents may know little for a number of reasons: the extent of some defects cannot be predicted at birth, experts often greatly disagree about the kind of lives defective infants will lead, many physicians are ill-informed about the nature and treatment of severe birth defeets, and some physicians have withheld information from parents. See, e.g., R. WEIR, SELECTIVE NONTREATMENT OF HANDiCAPPEd NEWBORNS: MORAL DILEMMAS IN NEONATAL MEdicine 59. 90 (1984); Hentoff, supra note 10, at 61; Robertson, supra note 21, at 460.

42. See, e.g., Moore v. East Cleveland, 431 U.S. 494, 506 (1977) (plurality opinion) ("the Constitution prevents East Cleveland from standardizing its children-and its adults-by forcing all to live in certain narrowly defined family patterns"); id. at 508 (Brennan, J., concurring) ("The Constitution cannot be interpreted . . . to tolerate the imposition by government upon the rest of us of white suburbia's preference in patterns of family living."); Wisconsin v. Yoder, 406 U.S. 205, 23031 (1972); Pierce v. Society of Sisters, 268 U.S. 510, 535 (1925) ("The fundamental theory of liberty upon which all governments in this Union repose excludes any general power of the State to standardize its children by forcing them to accept instruction from public teachers only."); Meyer v. Nebraska, 262 U.S. 390, 401 (1923). But see Prince v. Massachusetts, 321 U.S. 158 (1944). Although the holding in Prince does not serve the pluralism interest, Prince itself is most frequently quoted in a passage which does: "It is cardinal with us that the custody, care and nurture of the child reside first in the parents, whose primary function and freedom includc preparation for obligations the state can neither supply nor hinder. Pierce $v$. Society of Sisters . . ." 321 U.S. at 166.

43. 406 U.S. 205 (1972) .

44. Cf. Pierce v. Society of Sisters, 268 U.S. 510, 535 (1925): "The fundannental theory of liberty upon which all governments in this Union repose excludes any general power of the State to standardize its children by forcing them to accept instruction from public teachers only." 
munity and from the opportunities and choices which education through high school provides.

The "plurahism" rationale for parental rights is ironic in a second way. Where the plurahisn interest of the parents has been strongestwhere parents resist medical treatment for their children on specifically religious grounds-courts have readily found that the child's interest in physical health overrides the parents' interest in their religion, the child's interest in his soul, and society's niterest in pluralism. ${ }^{45}$ To put the ponit somewhat differently, when the parent's pluralism interest is strong, the state's interest is often strong as well, and frequently for the same reason-because the child's interests in the decision are also pressing.

Quite apart from these ironies, the usefulness of the "pluralism" rationale for parental rights is clouded by our vagueness about pluralism's status in American law. Everyone likes pluralism, where pluralism means only some loose kind of cultural tolerance. But the role of pluralism in American law has-outside of the area of freedom of religionbeen strangely neglected in scholarly writing, and the sporadic cases arguably espousing pluralism have hardly enunciated any discernible systematic doctrine. For example, pluralism as it is ordinarily understood speaks to the protection of diverse groups, yet the pluralism of the courts seems often to protect ad hoc social diversity. ${ }^{46}$ If pluralism serves the former interest, it has little to do with parental decisions about neonatal euthanasia, since few, if any, groups in American society make beliefs about that subject central to their way of life. If pluralisnı serves the latter interest, we are left uncertain just which kinds of "diversity" merit special protection. That uncertainty reflects another important constraint on the usefulness of the pluralism rationale for parental rights: we lack a sense of the limits of pluralism. Pluralism is not an absolute, and is perhaps not even a pre-eninent, value, since some conimon views about behavior and morals are necessary if society is to function at all, to say nothing of functioning well. And questions about when one human may end another's life are classically and properly central aniong the views about behavior and norals which society as a whole has been thought entitled, even obligated, to address.

\section{C.}

Thus far, I have argued that a rights approach to neonatal euthanasia is problematic because it relies on the inappropriate Mill paradigm and because the origin, scope, justification, and purpose of parental rights are uncertain. I want now to suggest that the rights approach is prob-

45. E.g., State v. Perricone, 37 N.J. 463, 181 A.2d 751, cert. denied, 371 U.S. 890 (1962).

46. Wisconsin $y$. Yoder is a notable exception. 
lematic in a third and final way. The problem has to do with the social and psychological consequences of treating issues like neonatal euthanasia in rights terms. It is hard to say to what extent the law should encourage people in their better impulses. Many of the law's attempts to do so-Prohibition comes to mind-have been morahistic in the narrowest sense and unsuccessful in the broadest sense. What, then, can the law reasonably ask of parents when deciding whether their severely impaired child should live? The difficulty of that question may be indicated by the rarity with which it is directly addressed. One begins, perhaps, by acknowledging that to ask parents to raise such a child is to ask them to suffer. ${ }^{47}$ One common response to that acknowledgement is that many parents have raised such a child, have found it rewarding, and have made it inspiring. Yet it seems callous to tell the parents of such a child to wait and they too will know the joys of difficult parenthood, and it seems presumptuous-and sometimes false-to tell them that eventually the joy will outweigh the pain. In any event, I doubt that we should suggest that the parents' decision ought to rest on the chances that they will, on balance and $m$ the end, benefit by it: I would suppose that parents have a moral obligation to their children independent of any such calculation, and I would suppose that we want to encourage parents to make their decision as selflessly as possible. Yet this last supposition leads toward the disquieting position the court in Regina v. Dudley \& Stephens maimtained:

It must not be supposed that in refusing to admit temptation to be an excuse for criine it is forgotten how terrible the temptation was; how awful the suffering; how hard in such trials to keep the judgment straight and the conduct pure. We are often compelled to set up standards we cannot reach ourselves, and to lay down rules which we could not ourselves satisfy. ${ }^{48}$

My project in this Essay is not to say whether, or how far, we should set up such standards and rules for decisions about neonatal euthanasia. But I do suggest that, even if law ought not, or can not, encourage people in their better impulses, we should at least be aware of ways in which law seems to encourage people in their meaner impulses. I wish to raise, cautiously, the possibility that, as a matter of practical psychology, to frame the question of neonatal euthanasia in terms of parents' rights is to encourage parents to be "self-concerning." In one important sense, of course, rights are "other-concerning": rights are an acknowledgment by society that its members have claims against it. But by the same token, and I think more commonly in ordinary thinking, rights are claims by individuals against society, and are "self-concerning." Thinking in terms

47. Robertson, supra note 40 , at 256-59.

48. 14 Q.B.D. 273, 288 (1884). 
of rights encourages us to ask what we may do to free ourselves, not to bind ourselves. It encourages us to think about what constrains us from doing what we want, not what obligates us to do what we ought. Legal rights are tellingly different from moral rights in this respect: When philosophers talk about rights, they commonly talk about a complex web of relationships and duties between individuals; ${ }^{49}$ when lawyers talk about rights, they commonly talk about areas of hiberty to act without interference. This difference is perhaps inevitable, since law's scope must be less than morality's, but this inevitability probably does not greatly affect the psychological consequences of the system of legal rights.

It is of course true that the system of legal rights is not limitlessly self-concerning, for most rights find some kind of limit in a conflicting right. But in the context of our discussion, that limit is precisely the problem, for it is not restrictive enough. Rights not only conflict with rights,

they conflict in the demands they make upon us with inoral considerations to which the concept of a right does not seem to apply at all: the requirement that we help someone in need, the generosity or kindness we ought to extend to persons simply out of love and affection for them $\ldots . .50$

But rights discourse encourages us to think of the clains of others on us in terms of their legal rights; the danger is that it may thereby encourage us to feel those rights fully describe the limits of what we owe them.

The self-concerning quahity of the rights approach to neonatal euthanasia may be see $m$ the extent to which it has become comfortable to weight the interests and even the ease of parents against the life of their child. This weighting of interests was perhaps foreshadowed in Roe v. Wade, where the Court seemed to found the very riglit to an abortion on the "detriments" suffered by a woman who could not liave an abortion. ${ }^{51}$ Similarly, writing about neonatal euthanasia, one leading medical commentator won the approval of one leading legal commentator when he said:

Fainilies know their values, priorities and resources better than anyone else. . . . If they cannot cope adequately with the child and their other

\footnotetext{
49. See, e.g., A. Melden, Rights ANd Persons (1977).

50. Id. at 1 .

51. In describing those detriments, the Court wrote:

Maternity, or additional offspring, may force upon the woman a distressful life and future. Psychological harm may be imminent. Mental and physical health may be taxed by child care. There is also the distress, for all concerned, associated with the unwanted child, and there is the problem of bringing a child into a family already unable, psychologically and otherwise, to care for it. ... [T] The additional difficulties and continuing stigma of unwed motherhood may be involved.
}

410 U.S. 113, 153 (1973). It is significant that the most imaginative attempt to justify Roe is based on the fact that "our law does not require people to be Good Samaritans." Regan, Rewriting Roe v. Wade, in The Law and Politics of Abortion 3 (C. Schneider \& M. Vinovskis ed. 1980). 
responsibilities and survive as a family, they may feel that the death option is a forced clioice. ... But that is not necessarily bad, and who knows of a better way. 52

As a logical matter, of course, one may have a right without exercising it or feeling encouraged to use it. But I have been speculating about what we might call the socio-psychological consequences of the mode of rights discourse that prevails in the United States today. My sense, which is strong but not susceptible of ready proof, is that this inode has encouraged us to feel that "to demand our rights, to assert ourselves as the moral agents we are, is to be able to demand that we be dealt with as members of the commumity of human beings. This is what moral dignity involves ...."53 The civil rights movement taught us the virtues of that attitude. But attitudes appropriate to civil rights may be inappropriate to privacy rights. Civil rights are rights to participate in self-government and society. Such participation is at least a virtue and may be a duty. But privacy rights are in a sense the opposite of civil rights-they are rights not to be affected by government and society-and to forego their use can be a virtue and even a duty. A person may, for example, have a privacy right to father more children than he can support, ${ }^{54}$ but he presumably has a moral duty to refrain from exercising that right. ${ }^{55}$ Yet as the law's rights discourse suffuses public discussion, such distinctions are easily obscured, lost in the fervor which attaches to the assertion of rights.

\section{IV}

One obvious response to the problems with the parental-rights approach to neonatal euthanasia has been to answer in kind by arguing that children or the handicapped have constitutional rights that offset such parental rights. Such a response has the attraction of seeming to put the risk of an erroneous decision on the parents (who stand to lose their happiness) instead of on the child (who stands to lose his life). I cannot in this Essay canvass the issues fully; my point, rather, is that here too a "rights" approach is awkward and inapt.

First, a children's rights approach is problematic for one of the same reasons a parents' rights approach is-it does not fit the Mill paradigm. The Mill paradigm, we may recall, involves a person versus the state. However, when we use children's rights (or the handicapped's rights) in the neonatal situation, we have two people - the child and the parent-as

52. Dr. Raymond Duff, quoted with approval in Goldstein, supra note 23, at 656 .

53. A. MELDEN, supra note 49 , at 25.

54. Cf. Zablocki v. Redhail, 434 U.S. 374 (1978).

55. For an extended discussion of trends in the relationship between morals and rights in family law, see Schneider, supra note 11 . 
well as the state. We lack here, as we did with parents' rights approaches, criteria for choosing between the two sets of rights. We encounter a further difficulty as well. Insofar as the state tries to protect children froni parents by strengthening children's rights, parents are inhibited froin protecting children from the state by the traditional means-invoking parents' rights.

Children's rights are incoinpatible with the Mill paradigm in another way. As Professor Sumner notes, "Rights theories have generally been formulated for the paradigm right-bearer-a competent adult huinan being. The existence of nonparadigm beings (children, infants, fetuses, the severely abnormal, nonhunian animals, perhaps also artificial intelligences) is awkward for such a theory."56 If we give people rights out of respect for their status as independent moral agents, it makes little sense to attribute rights to people who cannot be independent moral agents. This problem is particularly acute as to neonatal euthanasia, since severely retarded, newborn infants are patently incapable of making or articulating any kind of decision at all, and, unlike other children, they will never develop fully the ability to do so.

Children's rights, particularly in the context of neonatal euthanasia, differ from the Mill paradigm and from parental rights in yet another significant way. Parental rights are rights to make decisions unregulated by the state. But since children cannot make decisions for theinselves, children's rights are commonly formulated in terms of some view of what is good for children. In simple formulations, the right is a right "to life"; in the many grander formulations, the right is to the conditions necessary to make life happy. Thus a crucial inaptness of rights discourse is that it simply leads us back to the substantive questions about the benefits and costs, the wisdom or wickedness, of neonatal euthanasia. One attraction of a rights approach is that it seens to relieve society of these difficult questions and to transfer decisions to those most concerned. Where a rights approach serves neither function, its utility is markedly weakened.

One way out of the dilemma of a right which must be defined in terms of the substantive questions about neonatal euthanasia inight seem to be to establish not a right to a particular kind of result, but a right to a choice inade on behalf of the child. However, if newborn children are to have rights of choice, someone must exercise them. That someone is ordinarily the parent, but in relation to neonatal euthanasia it is precisely the parent whose influence one attempts to check by assigning children rights. That someone cannot be the state, because privacy rights are precisely rights to be free of state supervention. A failure to understand that

56. L. SUMNer, AbORTION AND MORAL TheORY 56 (1981). 
fact about privacy rights creates the anomaly of cases like Bellotti $v$. Baird. ${ }^{57}$ There the Court was so anxious to protect the child's right to have an abortion that it gave the right to decide whether she should have an abortion to the state, although the rationale of Roe $v$. Wade was that a woman should be able to decide whether to have an abortion free of government interference. Even if the anomaly of a privacy right exercised by the government could be overcome, it still would not be clear how that right should be exercised for the child. There is no way to know how any particular newborn child, much less a severely retarded child, would exercise his rights, ${ }^{58}$ and thus one is again cast back to the basic substantive questions about neonatal euthanasia. It is instructive and (from the perspective of advocates of rights for children and the handicapped) ironic that, when courts have attempted to think in terms of the rights of patients unable to speak for themselves, they have not uncommonly interpreted those rights as rights to die, not to live. ${ }^{59}$

I have thus far undertaken to explain sone of the factors that impair social and legal discussion of neonatal euthanasia. I have sought to do so by showing that one of the inodes of discourse used in discussing neonatal euthanasia-nainely rights discourse-has been inapt and awkward in both of the nrajor forms in which it has been eniployed. I will now argue that rights discourse has other defects that further impair its usefulness in considering neonatal euthanasia. I said earlier that the "liberal" position on neonatal euthansia has generally been that parents have the right to decide whether their children will receive medical treatment, and that the "conservative" position has generally been that all children have a right to life. But I also said that each side's position abounds with anomalies. We can better understand those anomalies, and consequently the debate over neonatal euthanasia, by recognizing how genuine, numerous, and steep are the shippery slopes that complicate each rights-view. These

57. 443 U.S. 622, 647-48 (1979).

58. As Professor Robertson notes:

The danger is judging the infant's situation from the perspective of normal adults who were suddenly deprived of their capacities, rather than from the perspective of one with no alternative but dcath. Even if a reasonable person facing irremediable pain or minimal participation in the affairs of life might find trcatment harmful, we cannot be sure that one less well-endowed and experienced, would. . . . Curiously, proponents of non-treatment have not attempted to dispel the charge of egocentrism by asking defective children who have survived to adolescence or adulthood whether they find their lives worse than death, and whether they would have preferred non-treatment.

Robertson, supra note 21 , at 456.

59. E.g., In re Quinlan, 70 N.J. 10, 355 A.2d 647, cert. denied, 429 U.S. 922 (1976). For a perceptive analysis of the problems that arise when courts try to exercise the "privacy" rights of patients unable to make decisions for themselves, see Buchanan, The Limits of Proxy DecisionMaking, in Paternalism 153-70 (R. Sartorius ed. 1983). 
slopes may work either to intensify a side's commitment to its rights view (by revealing ways in which such a commitunent is necessary to protect other rights to which a side is committed), or to erode that commitment (by revealing ways in which that commitinent conflicts with other rights the side espouses). But in either event a side's position is easily distorted by its efforts to cope with the surrounding slippery slopes.

A.

Liberals have been influenced in formulating and defending their position by several shippery slopes. The first such slope is the possibility that making neonatal euthanasia acceptable might legitimize involuntary euthanasia of adults. For at least a century, some liberals have advocated loosening legal constraints on euthanasia. But they have generally been careful-either out of conviction or strategy-to limit their arguments to voluntary euthanasia. ${ }^{60}$ Indeed, as Professor Burt notes, "A generation ago proposals for authorizing voluntary euthanasia for terminally ill adults were inet, in part, by assertions that such practices would lead to euthanasia for defective newborns. Proponents of voluntary euthanasia rejected this argument, in effect, as implausible and wholly fanciful."61 The practice of neonatal euthanasia brings us to the borderland of involuntary euthanasia and to many troubling questions about which other groups might be subject to it, with all the disturbing associations with "the elimination of the unfit" such questions carry. ${ }^{62}$ All this makes it desirable to find handholds on the slope toward involuntary euthanasia. One such handhold has been the distinction between "active" and "passive" euthanasia: if euthanasia is confined to those who will die if not treated, some limits have been placed on the scope of involuntary euthanasia. But the debate over neonatal euthanasia has strained that distimction too: its advocates have generally argued only for passive euthanasia (that is, death by nontreatment), but passive euthanasia can cause deaths so horrifying that active euthanasia begins to seem humane.

This first slippery slope poses a variety of dilemmas for the liberal position on neonatal euthanasia. To those liberals who favor involuntary euthanasia, the slippery slope from neonatal euthanasia to involuntary euthanasia of adults should be troubling only tactically. But the tactical problem is not insubstantial. And to those-liberal or conservativewho oppose involuntary euthanasia, that slope raises intractable questions about how neonatal euthanasia can be distinguished from other forms of involuntary euthanasia. Further, even if satisfactory logical dis-

60. Kamisar, Some Non-Religious Views Against Proposed "Mercy Killing” Legislation, 42 MiNN. L. REV. 969, 1027 (1958).

61. Burt, supra note 7, at 439 (footnote omitted).

62. Kamisar, supra note 60 , at 1031-33. 
tinctions can be found, applying them must almost surely be difficult. ${ }^{63}$ Finally, there remains what might be characterized as a psychological aspect of slippery slopes: they work partly by domesticating one idea and thus making its nearest neighbor down the slope seem less extreine and unthinkable. In the context of neonatal euthanasia, this process sparks the fear that even an extension of euthanasia that is logically defensible will be psycliologically brutalizing. As Professor Burt warns,

When we find ourselves authorizing death for the deformed, we must also vicariously harden our hearts to the deformities we all feel, circumscribing the range of abnormality we are willing to accept in ourselves. As we do this to ourselves ... we are pushing along in barely perceptible steps the internal psychological processes which permit us one day rationally, coolly, bloodlessly, to consider what today seens wildly beyond possibility. ${ }^{64}$

The liberal's coinmitment to parental freedoin to choose neonatal euthanasia is hardened by his second slippery slope. This slippery slope suggests that, to countenance doubts about the parents' right to choose neonatal euthanasia is to encourage doubts about women's right to choose abortion: If neonatal euthanasia is wrong or is a question for social, not private, decision, why is not abortion wrong, or a question for social decision? Given the centrality the right to an abortion has assumed in much liberal thinking, this slippery slope, by endangering that right, impels the liberal more adamantly to defend the parental right to choose neonatal euthanasia. Nor can this slippery slope be easily avoided. On the contrary, atteinpts to distinguish between the moral status of the fetus and the new-born child have long been deeply perpleximg. ${ }^{65}$ Roe $v$. Wade sought to create a handhold along the slippery slope by making viability the point at which the state may forbid abortions. The Court selected viability "because the fetus then presuinably has the capability of meaningful life outside the inother's womb."66 But what is "meaningful hife"? What is the moral difference between a fetus which will soon begin to live a normal life and a severely retarded, severely liandicapped newborn child who will never have one? If even severely defective newborn children are endowed with rights, can fetuses, logically and pohtically, be denied the same rights? ${ }^{67}$ The liberal's concern

63. See Schauer, Slippery Slopes, 99 HARV. L. REV. 361 (1985).

64. Burt, supra note 7 , at 440 .

65. See generally L. SUMner, supra note 56; M. TOOLEY, ABORTION AND INFANTICIDE (1983).

66. 410 U.S. 113,163 (1973).

67. As one liberal journalist reports,

To my knowledge, no organization of liberals or civil-rights groups has ever said a word about the rights of Baby Doe. Nor has any feminist group .... .

I have discovered, moreover, that most members of these groups do not take kindly to questions on the subject. Some liberals and feminists, for instance, have told me sharply 
over these imponderable questions is exacerbated by the apparent vulnerability of Roe v. Wade: As a substantive due process case, Roe suffers from the stigma of Lochner; among substantive due process cases, it is one of the few that overrules a law that was neither anachronistic ${ }^{68}$ nor eccentric; ${ }^{69}$ and (partly because of those facts) it attracts as much political loathing as any recent Supreme Court case.

A third slippery slope pulls the liberal away from his position on neonatal euthanasia. This silope embodies the fear that to emphasize the parental right to choose neonatal euthanasia is to risk eroding children's rights and the rights of the retarded. The conflict between children's rights and parental rights has long bedeviled the liberal: while the two rights can usefully harmonize, ${ }^{70}$ they can as easily clash. ${ }^{71}$ Indeed, the Court has generally declined even to attempt to construct a doctrine of children's rights, largely because of the difficulty of working out the relation between the two sets of rights. ${ }^{72}$ When the Court has occasionally accorded children rights, it has done so ad hoc and for reasons largely responsive to the particular considerations of each case. For example, the rights of daughters who wish to have an abortion without their parents' consent may perhaps be best understood in terms of the Court's elaboration of the right to an abortion. Where children's rights have been most systeniatically developed-in juvenile justice-the state, not the family, is the entity with which the child is thought to be in conflict, there is an easily adapted standard (adult criminal-procedure rights) to consult, and the area is so circumscribed that a shppery slope into other kinds of children's rights is unlikely.

The conflict between the rights of the retarded and of parents is less developed, since parents have generally spoken for the rights and welfare of their retarded children, but it has of late been emerging in complex and troubling ways. For example, in Pennhurst State School and Hospital v. Halderman, ${ }^{73}$ reformers and parents of retarded children who wished to close an institution for retarded children found themselves opposed by parents of retarded children who wished to keep the institution open. Each side had some reason to claim that it spoke for the

that if I were to look more closely at the kinds of people trying to save those Baby Does, I would understand that such rescue efforts are a way to make women subservient again to those who would tell them what they can and cannot do with their own bodies.

Hentoff, supra note 10, at 56.

68. Cf. Griswold v. Connecticut, 381 U.S. 479 (1965).

69. Cf. Meyer v. Nebraska, 262 U.S. 390 (1923).

70. As they secm to have in, for instance, Tinker v. Des Moines School Dist., 393 U.S. 503 (1969).

71. E.g., H.L. v. Matheson, 450 U.S. 398 (1981); Parham v. J.R., 442 U.S. 584 (1979); Wisconsin v. Yoder, 406 U.S. 205 (1972).

72. E.g., Parham v. J.R., 442 U.S. 584 (1979); Wisconsin v. Yoder, 406 U.S. 205 (1972).

73. 451 U.S. 1 (1981). 
rights of the retarded, and the only way to decide what those rights were seemed to be to return to "substantive" questions about what methods of care and treatment best serve the retarded. ${ }^{74}$

\section{$B$.}

Conservatives too have their slippery slopes. The first slope runs from parental rights toward children's rights. That is, the more conservatives defend their position on neonatal euthanasia in rights terms, the more they are led to defend rights (children's rights) which they view as subversive of the proper authority and rights of parents. This slippery slope, like some of the liberal slopes, is ancient: although conservatives have been enthusiasts for parental rights, ${ }^{75}$ they have also been relative enthusiasts of state regulation of familial affairs. ${ }^{76}$ Conservatives might argue that their shppery slope has a useful handhold by which they may prevent their preference for children's rights here from leading to children's rights more generally. This handhold is the principle that the parent's right of control ends at the child's (absolute?) right to life. Yet while this principle is consistent with the conservative position on abortion, it is hardly a full statement of the ambivalent conservative position on the relations of the family and the state.

The conservative's second slippery slope does not threaten his position, but drives him to affirn it more resolutely. That slope expresses the fear that to allow neonatal euthanasia is to promote a distinction between people who are inherently worthwhile and those who are not. The conservative's perception of this slope is described in Professor Luker's fascinating study of women active in the pohtical controversy over abortion. She notes, "A considerable amount of social science research has suggested, at least in the realm of medical treatment, that there is an increasing tendency to judge people by their official (achieved) worth."77 She suggests that anti-abortion activists detest that distinction:

To insist that the embryo is a baby because it is genetically human is to make a claim that it is both wrong and impossible to make distinctions between humans at all. Protecting the life of the embryo, which is by definition an entity whose social worth is all yet to come, means protecting others who feel that they may be defined as havimg low social worth;

74. See Burt, Pennhurst: A Parable, in R. MNook1N, supra note 14, at 265-363 (1985). Neonatal euthanasia itself has in fact put many liberals at odds with the ordinarily liberal "advocates" for the retarded. See, eg., Biklen \& Ferguson, In the Matter of Baby Jane Doe: Does Reagan Really Agree with Us?, Soc. PoL'y, Summer 1984, at 5.

75. E.g., H.L. v. Matheson, 450 U.S. 398 (1981); Medeiros v. Kiyosaki, 52 Haw. 436, 478 P.2d 314 (1970) (relationship of parental rights and state sex-education program).

76. E.g., Zablocki v. Redhail, 434 U.S. 374 (1978).

77. K. LuKer, Abortion and the Politics of Motherhood 207 (1983). 
more broadly, it means protecting a legal view of personhood that emphatically rejects social worth criteria.

For the majority of pro-life people we interviewed, the abortions they found most offensive were those of "damaged" embryos. This is because this category so clearly highlights the aforementioned concerns about social worth. ${ }^{78}$

This slippery slope, as Professor Luker's reference to the abortion dispute suggests, in one sense corresponds to the liberal's slippery slope away from the right to an abortion. But in another, ironic, sense, this slippery slope, which confirms conservatives in their thinking about neonatal eutlianasia, seems to lead toward principles liberals espouse: "Caring for defective newborns . . . reinforces societal commitment to values of life, equality, and the non-allocation of rights by meritocratic or other discriminatory [?] principles and thus produces respect for the life and moral equality of all persons."79

C.

The ubiquity of the slippery slope problems surrounding the issue of neonatal euthanasia should not surprise us. Slippery slopes are likely whenever we wish to serve the interests of more than one person and whenever one person's good is complex; Dr. Johnson long ago reminded us that when we walk toward one blessing, we walk away from another. Slippery slopes develop when we try to secure both blessings at once.

Shippery slopes also develop when a legal principle becoines so expansive that it threatens surrounding values or comes to encompass within itself conflicting values. Shppery slopes are thus likely consequences of an adversary legal system in which lawyers are always encouraged always to press " $[t]$ he tendency of a principle to expand itself to the limits of its logic." 80 And shippery slopes may be particularly likely when the "privacy" right is at stake, for that right has uncommon expansive potential. Some rights can be limited by consulting the words in whicl the right is stated. Thus a right of free speech seems hinguistically confined to activities that have some plausible relation to speech. ${ }^{81}$ Some rights can be limited by consulting their purpose. The right to free speech, for instance, has sometimes been limited by an understanding that its purpose is to make a fully democratic society possible. But the privacy riglit is susceptible of neither limitation, because the Supreme Court has avoided stating what the privacy principle is, and neither

78. Id.

79. Robertson, supra note 21 , at 458.

80. B. Cardozo, The Nature of the Judiclal Process 51 (1921). See Schauer, supra note 63 , for an illuminating discussion of slippery slopes in the law.

81. Even here, of course, the relationship of symbolic acts to speech has raised slippery slope problems. 
courts nor commentators have convincingly articulated its purpose. ${ }^{82}$ Rather, the privacy right has been developed by a frankly analogic process. ${ }^{83}$ A principle developed by analogy need not be limitless; lawyers can be wonderfully adept at distinguishing cases. But "every fact leads to every other," 84 and analogy can build on analogy to lead who knows where. To cabin the right of privacy, the Supreme Court has relied not on some inherent characteristic of the right, but rather on balancing the right against state interests. However, since the privacy right and the state interest cannot be expressed in commensurable terms, that technique provides no secure or predictable limits. ${ }^{85}$ These difficulties of dehmiting the right of privacy are intensified by the way the Mill paradigm encourages us to believe that the costs of extending the right will be distributed among all of society and by our appreciation of the liberating history of rights thinking:86 An apparently costless, historically beneficial right is a concept prone to unreflective extension. But, as the breakdown of the Mill paradigm reminds us, extending the privacy right leads to situations in which serving one person's privacy right disserves another person's rights and interests and to the slippery slope problems such tensions produce.

We may close this discussion of slippery slopes by noting that, from one perspective, they too indicate the inaptness of the rights discourse. The presence of difficult slippery slopes suggests the presence of conflicting interests which are incommensurable. Such conflicts demand some kind of accommodation. But when interests are described as "rights," accommodation is impeded. Defining an interest as a right masks the nature and complexity of what is actually at stake; defining an interest as a right makes accommodation seem arbitrary, since we lack a hierarchy of rights to help us choose between them; and defining an interest as a right makes accommodation seem to be the breaching of a right or the defining away of a right and thus, a moral and political wrong.

Fourteenth amendment jurisprudence tries to create such accommodations by balancing the state interest against whatever private rights are asserted. But it is both a symptom and a cause of the rights mode of legal discourse that state-interest analysis is the least developed part of

82. See Note, supra note 37 , at $\mathbf{2 8 8}-\mathbf{9 3}$, for a statement of the need for a limiting principle for the privacy right and a struggle to find one.

83. E.g., Roe v. Wade, 410 U.S. 113, 152-53 (1973).

84. O.W. Holmes, The Profession of the Law, in Collected Legal Papers 30 (1920).

85. The fiexibility of the technique cuts both ways, of course. Thus it has been argued that balancing ought not be used in first amendment cases because it permits excessive restrictions on the right to free speech. For an analysis of the use of state interests to limit the privacy right, see Schneider, State-Interest Analysis in Privacy Law: An Essay on the Constitutionalization of Social Issues, 51 LAW \& CONTEMP. Probs. (1988).

86. See W. Sullivan, Reconstructing Public Philosophy 60 (1982). 
fourteenth amendment law. In judicial opinions, that analysis is often perfunctory and pro forma. In scholarly commentary, it is often slighted in discussions of particular issues and regularly ignored as a separate topic of inquiry, especially compared to the cascade of attention given to questions about identifying and enforcing rights. ${ }^{87}$ In sum, the slippery slopes I have described are a further indication that rights discourse, as it is presently practiced, lacks the resources that would equip it to be an effective vehicle for the resolution of a social issue like neonatal euthanasia.

\section{VI}

I have argued that rights discourse is, in its present form, an inapt means of discussing problems like neonatal euthanasia. In particular, I have argued that there is no rights approach which does not appear (at least on this prelimmary investigation) to suffer crippling drawbacks, drawbacks of which various shippery slopes are both a symptom and a cause. The significance of my argument, if such there be, hes in the doubts it expresses about a deeply ingrained, deeply useful mode of social and legal thought. Yet these doubts have their limits: they are directed toward rights discourse as we now know it, and rights discourse might eventually develop the kind of "satisfactory theory of basic human rights and their relationship to other values pursued through law" enhance its usefulness. Further, some of the inadequacies of rights discourse may be due to conflicts in social values which will some day be resolved. In any event, while my doubts about rights discourse may all be justified, I liave not asked what alternative forms of social discussion would be preferable.

This Essay, however, is not the place to propose an alternative to the rights mode of discussing neonatal euthanasia. Instead, I return to an observation I made at the beginning of this Essay. There I noted that the rights approach and the committee approach have in common the purpose of avoiding social discussion of the substantive issues of neonatal euthanasia. ${ }^{89}$ Yet the rights approach serves that purpose poorly, for those issues persist even in discussions phrased in rights terms. To some extent, for instance, the jurisprudence of rights attempts to factor in substantive issues when it selects and defines the rights to be employed. Thus, we saw that questions of children's rights and of the handicapped's rights regularly devolve into questions about the substantive desirability

87. For an attempt to remedy that neglect, see Schneider, supra note 85.

88. H.L.A. HART, 1776 - 1976: Law in the Perspective of Philosophy, in Essaxs IN JuRISPRUdence AND Philosophy 158 (1983).

89. See supra Part II, Section $A$. 
of neonatal euthanasia. ${ }^{90}$ Substantive considerations that are not factored into the definition of a right seek accoininodation elsewhere. Yet we saw that the rights frainework in which accoinmodation is sought is often unsuited to the purpose. In short, the substantive issues of neonatal euthanasia are neither effectively escaped nor well resolved by the rights approach.

The committee approach to neonatal euthanasia, of course, relieves society as a whole of the debate over the substantive issues and leaves thein to be thrashed out case by case by many discrete committees. Yet I believe it is a failure of both the rights approach and the committee approach that they seek to avoid a social debate of these issues. This belief is of course controversial and raises questions that themselves deserve an essay. Here let me say only that the issues involved in neonatal euthanasia seein to ine matters in which society as a whole has an interest, which it may legitimately bring into public discourse, and for which it inay, as in some ineasure it now does, legitimately try to set standards.

Society as a whole has an interest not just in setting standards for the treatment of severely handicapped infants, but in helping both them and their parents. Politically, that help will most surely be provided if soine sense of communal responsibility for inpaired infants and their parents is widely felt. There is nothing logically inconsistent between such a sense of communal responsibility and the rights approach. Indeed, a community with a developed sense of inutual responsibility nay gladly acknowledge a wide range of rights against itself. Yet it seems to ine possible that, as a practical matter, the rights approach, when used too broadly, erodes such a sense of responsibihity. A commumity that atteinpts to unite itself largely in terms of the rights each citizen has against the whole has little to stimulate in each citizen concern for his fellows. ${ }^{91}$ A community that rehes too coinpletely on rights thinking can too readily slip into viewing riglits as stating the maximum as well as the minimuin it owes to its citizens. Thus, I hope that an approach to neonatal eutlianasia based on a sense that society has a legitimate interest in the issue might stimulate a sense that society has a duty to commit resources to what would be seen as a common problem.

\section{VII}

In closing so skeptical an Essay, I perhaps owe the reader some

90. See supra text accompanying notes $56-59 \& 74$.

91. For an argument that, as compared with Western Europe, the United States has a family law both much more oriented to rights and much less committed to assisting families, see $M$. Glendon, Abortion and Divorce in Western LAW: AmERICAN Failures, European Challenges (1987). 
clearer, more specific sense of how I would begin to confront, if not resolve, the practical dilemmas of neonatal euthanasia. Because of the difficulties I have described with the rights approach to neonatal euthanasia, and because I share the skepticism of other commentators about "legalizing" these decisions by adopting the committee solution, 92 I would hesitate to change the law on the books, despite its disjunction with the law in action. I would, at least temporarily, retain the law on the books while society, in the numerous ways available to it, debates the social and moral quandary neonatal euthanasia presents. I am drawn to this tentative conclusion because I see human hife as an ultimate value; because I believe the helpless and deformed deserve compassion, not calculation; and because I beheve it would be degradimg to live in a society which permitted children to die because they are burdensome. I concede that euthanasia is soinetimes proper, though $I$ believe such occasions are extraordinary and few. But like other commentators, I do not see how standards can be written whicli limit euthanasia to those few cases, which do not depersonalize questions of life and death, which do not dangerously diffuse responsibility for people's lives, which do not ask the state to endorse the primciple tliat some lives are not worth living. Perhaps these are very personal reasons, but they seem to me directed toward a question of legitimate public concern.

I see this, then, as a matter involving important moral principles. Others see it as a matter mvolving important huinan rights. Tlie danger of either view is that botli moral principles and human rights are commonly felt to be, and to some extent ought to be, uncompromisable. But in a complex democracy, soine compromise of both principles and rights, some decent respect for the opimions of others, some realization that time has upset inany fighting faiths, are necessary. It seeins to me a fault of the rights approacli that it impedes compromise and even makes it odious. As I wrote above in a somewhat different context, rights discourse masks tlie nature and complexity of the interests actually at stake; turns the accommodation of interests into the breaching or defining away of a right, and thus a pohtical and moral wrong; and, because of the absence of a hierarchy of rights, nuakes choices between interests harder. Further, defining interests as rights inhibits coinpromise because tlie pull of surrounding shppery slopes makes a whole system of rights, and not just the question of neonatal euthanasia, seem to be at stake. On the otlier hand, a virtue of the present state of the law is that it may ease compromise. First, as Professor Mnookin observes, ${ }^{93}$ the dicliotomy between the law on the books and tlie law in action represents a compromise, a com-

92. E.g., Burt, supra note 7, at 441-43; Mnookin, supra note 8, at 682; Robertson, supra note 40 at 26465 .

93. Mnookin, supra note 8 , at 667 . 
promise all the more attractive because unacknowledged. Second, the present law allows each state to regulate the problem in its own way. Since there are still important differences in social attitudes between many states, federalism seems to me to permit a useful, though neglected, form of compromise. ${ }^{94}$

I said that my conclusion was hesitant. Whether the law responds adequately to a problem depends on the problem's scope, and we lack a clear sense of how common neonatal euthanasia actually is, or of how unbearable the lives of its victims actually were or were to be. I hesitate out of fear that cases like that of Phillip B. may be common. He is a Down's Syndrome child. His IQ is 57 . He will someday be able to learn a job and to live semi-independently or perhaps even independently. ${ }^{95}$ He can know "true love and strong feelings."96 When he was twelve, he needed a heart operation to prevent his gradual suffocation. His parents, with whom he had never lived, refused to permit the operation, and the Califorma courts refused to order it. ${ }^{97}$ Custody of Phillip has now been sought by and given to a couple who befriended him, and he has, belatedly but successfully, had the operation. ${ }^{98}$ If mere retardation, to say nothing of retardation so mild, is commonly cause for denying children medical care, I hope the law in action, at least, will change.

94. For a more complete discussion of the desirability of social compromise over family law issues and of the difficulty of achieving compromise through rights discourse, see Sehneider, supra note 11 .

95. Guardianship of Phillip B., 139 Cal. App. 3d 407, 419, 188 Cal. Rptr. 781, 788 (1983).

96. Id. at $417,188 \mathrm{Cal}$. Rptr. at 787.

97. In re Philhip B., 92 Cal. App. 3d 796, 156 Cal. Rptr. 48 (1979) (cert. denied, 445 U.S. 949 (1980).

98. N.Y. Times, Oct. 10, 1983, at A12, col. 1. The lawyer for Phillip's new guardians believed that the case emphasizes that " institutionalized retarded children, like other children, are entitled to have their basic human needs met, including the need for love and emotional support; the need for educational and developmental guidance to help them enter society and the need for essential medical care." "To Phillip's natural father, "the case represented an 'outrageous' intervention by the state "in the rights of parents to make decisions concerning their children.' " Id. 


\title{
CALIFORNIA LAW REVIEW
}

\author{
VOLUME LXXVI \\ JANUARY
}

COMMENTS

School of Law, Boalt Hall

UNIVERSITY OF CALIFORNIA

Berkeley, California

1988

Copyright @ 1988 by California Law Review, Inc. 


$$
\text { . }
$$

